\title{
EXTRACTION AND IDENTIFICATION OF MAJOR POLYPHENOL CONSTITUENTS OF NORTHERN HUNGARIAN HORSEMINT (MENTHA LONGIFOLIA L. (L.))
}

\section{Katalin Patonay ${ }^{*}$, Orsolya Szabó-Hudák1, Helga Szalontai ${ }^{1}$, Mihály Jánószky1, Erika Pénzesné Kónya ${ }^{2}$ \& Éva Zámboriné Németh ${ }^{3}$}

${ }_{1}^{1}$ Food and Wine Research Institute, Eszterházy Károly University, 6G Leányka u., $H$ 3300, Eger, Hungary; ${ }^{2}$ Department of Botany and Plant Physiology, Eszterházy Károly University, 6D Leányka u., H-3300, Eger, Hungary; ${ }^{3}$ Department of Medicinal and Aromatic Plants, Szent István University, 29-43 Villányi u., H-1118, Budapest, Hungary; *E-mail: patonay.katalin@uni-eszterhazy.hu

\begin{abstract}
Mentha longifolia (L.) L.) is a less studied species from the viewpoint of its nonvolatile constituents and this work is the first phytochemical screening of it in Hungary. The aim of the experiments is to elaborate an efficient extraction method of its polyphenolic antioxidants. Thirty-six accessions were sampled. Soxhlet and an ultrasonic extraction were applied, both with methanol $(\mathrm{MeOH})$ and ethanol:water 7:3 (WA). The analysis of the extracts was carried out by HPLCDAD method. Rosmarinic acid, hesperidin, diosmin and cynaroside were observed to be common constituents of all samples. Other major constituents were observed in all of the chromatograms at ca. $t_{R}=13.5 \mathrm{~min}$. and $t_{R}=19.7$ min (unknown $A$ and B). Their identification needs further examination. Regarding antioxidant activity, WA extraction was more efficient than $\mathrm{MeOH}$ Soxhlet extraction.
\end{abstract}

Keywords: Mentha longifolia, horsemint, polyphenolic antioxidants, HPLC, antioxidant activity

\section{INTRODUCTION}

Horsemint, Mentha longifolia (L.) L., Lamiaceae (further: ML) is a wild-growing perennial species. It has a large distribution area in Eurasia and non-tropical Africa (Tucker and Naczi 2007), grows in multiple types of habitats such as wet meadows, roadsides and urban areas (Başer et al. 1999). Active ingredients of ML originate from the mevalonate and shikimate pathways. The former produces the volatile terpenes of ML, most frequently ketones as carvone, piperitone, piperitenone and corresponding epoxides 
(Başer et al. 1999; Sharopov et al. 2012). Triterpenes in ML (ursolic, oleanolic acids etc.) also originate from this pathway. The shikimate pathway is the origin of phenolics of ML. Caffeic acid derivatives (predominantly the known antiradical molecule rosmarinic acid) are present. But flavonoids also deserve attention: the presence of 55 different flavonoids was reported (Bourwieg and Pohl 1973; Ghoulami et al. 2001; Pereira and Cardoso 2013 Hawrył et al. 2016, Patonay et al. 2017; Park et al. 2019), six of them de novo (Sharaf et al. 1999; Jahan et al. 2001; Ghoulami et al. 2001; Ali et al. 2002). Regarding flavonoid subclasses, flavones seem to be present in the largest variability.

There are several studies dealing with the phytochemistry of horsemint, although the majority of them deals with volatile terpenoids. Studies focusing to polyphenolic constituents most frequently evaluate a single sample of the species (e. g. Bourwieg and Pohl 1973; Sharaf et al. 1999; Jahan et al. 2001; Ghoulami et al. 2001; Ali et al. 2002; Fialová et al. 2008; Krzyzanowska et al. 2011; Shen et al. 2011; Stanislavljević et al. 2012; Benedec et al. 2013; Bahadori et al. 2018; Park et al. 2019). Relevant studies on a larger representative sample pool dealing with flavonoid composition of horsemint are not available, in contrary to e.g. peppermint (Guédon and Pasquier 1994). For the major nonflavonoid phenolics of horsemint, one single large-sample study has been found (Dudai et al. 2006) providing the rosmarinic and caffeic acid contents of 40 different clones. Therefore, it can be established, that conclusions on the distribution pattern of polyphenols in horsemint populations and on the factors influencing their accumulation would be difficult. Additionally, a part of the former studies does not provide a detailed description of the extraction method applied, making the comparison of data difficult (e. g. Ghoulami et al. 2001; Jahan et al. 2001; Benedec et al. 2013). Thus, contrary to the abundance of this species, knowledge on its phytochemistry, especially in case of the polyphenolic compounds, still seems to be incomplete. The present study on the extractability and polyphenol composition of the Northern Hungarian ML populations has been carried out in the framework of a wider project which intends to utilize this species as a cultivated source of antioxidant and/or preservative preparations in the food industry. Thus, one step is to define an effective extraction method of horsemint resulting in the highest antioxidant capacity and polyphenol content of the 
samples. In parallel, screening the polyphenol composition supplements our knowledge on this species and may help in elucidating the background of the antioxidant properties.

\section{MATERIALS AND METHODS}

Sampling: Thirty-six shoot samples of ML were collected in the flowering stage, from the end of June to the beginning of October, 2016. Populations in the Bükk Mountains, Mátra Mountains, HevesBorsodi Hills and Eger were surveyed. Identification: one item (ID: NOSZ) by the collector Jana Táborská (Eszterházy Károly University, Department of Botany and Plant Physiology) ten items (JOF, HV1, HV2, HV3, HOV1, HOV2, HOV3, KÜH, JÁV and EGR4) by the collector Helga Szalontai and other samples: by Erika Pénzesné Kónya. The identification was performed on the basis of macromorphology, using the manual of the vascular flora of Hungary (Simon 1994). Voucher specimen deposition: at the Eszterházy Károly University in the chemotaxonomical collection of the herbarium (EGR-CH). Samples were hung in a shady place for 21 days. After drying, leaves and inflorescences were separated from stems, collected and deposited in the freezer.

Extraction. Extraction in a cooled ultrasonic bath $(45 \mathrm{kHz}, 3$ stages, $45 \mathrm{~min} / \mathrm{stage}$, at maximum $30^{\circ} \mathrm{C}$ ) was applied. Sonication may be expected to be milder toward many plant polyphenols of heat sensitivity as it can be performed at room temperature and normal pressure. Another advantageous traits of this method are the much lesser time demand and moderate solvent demand in comparison with Soxhlet extraction or the conventional room temperature maceration of plant material (Medina-Torres et al. 2017). Furthermore, for rosmarinic and carnosic acids it was observed that the sonication gives better yield of them in comparison with conventional room-temperature maceration of rosemary leaves, both in case of methanolic and ethanolic extractions (Paniwnyk et al. 2009) and the antioxidant activity of extracts gained by ultrasonic treatments is higher than the values of extracts prepared by maceration. A comparative study on extraction of polyphenols of Tilia cordata inflorescences established that the sonication was the most efficient method to extract phenolic acids of Tiliae flos and the second efficient method to gain flavonol constituents of it when sonication, microwave 
extraction, accelerated solvent extraction, heat reflux extraction, and Soxhlet were compared (Oniszczuk et al. 2015)

In parallel, the Soxhlet method was applied as a reference method, as nowadays it is still frequently used to extract different plant materials (e. g. Ahmed et al. 2015) including horsemint (e. g. Güllüce et al. 2007; Iqbal et al. 2013) and in comparative investigations on extractability of some plants (Karabegović et al. 2011). The solvents were methanol $(\mathrm{MeOH})$ and 7:3 ethanol: water mixture (WA). Methanol $(\mathrm{MeOH})$ was taken as a reference, as for this species a significant part of investigators use it when polar extracts are prepared (e.g.: Hajlaoui et al. 2009; Güllüce et al. 2007; Iqbal et al. 2013; Murad et al. 2016). The aqueous ethanol with 7:3 ethanol: water ratio (WA) is not frequently mentioned in the references on this species (Mimica-Dukić et al. 1999; Stanislavljević et al. 2012; Benedec et al. 2013) however, the solvent is applied in pharmaceutical practice to prepare polyphenol rich tinctures i. e. from common tormentil (Potentilla erecta) rhizome (Kőszeginé Szalai et al. 2003). In this manner, four different extracts of each of the thirty-six horsemint samples were obtained.

In vitro antioxidant parameters Antiradical activity was investigated by DPPH assay $(0.1 \mathrm{mM}$ DPPH in ethanol/30 $\mathrm{min} /$ room temperature/normal light). Results are given in $\mathrm{EC}_{50}$ $\mathrm{mg} / \mathrm{l}$ extract. This means the concentration of the extract consumes half of the initial concentration of DPPH, thus a lower value means stronger activity. Reducing ability was investigated on FRAP assay. Briefly, a modified method of Benzie and Strain (1996) was used at the assay. Fifty $\mathrm{ml}$ of buffer $(46.3 \mathrm{ml} 0.2 \mathrm{M}$ acetic acid plus $3.7 \mathrm{ml}$ of $0.2 \mathrm{M} \mathrm{Na}$-acetate filled to $100 \mathrm{ml}$ ) was measured in with $5 \mathrm{ml} 10 \mathrm{mM}$ 2,4,6-s-tripyridyl-triazine (TPTZ) acidified with $84 \mu \mathrm{l} \mathrm{cc} \mathrm{HCl} / 25 \mathrm{ml}$ solution. In the last step $5 \mathrm{ml} 20 \mathrm{mM}$ ferric chloride was added to the mixture. $50 \mu \mathrm{l}$ of sample with $1450 \mu \mathrm{l}$ of this mixed reagent was reacted for 5 min (under normal light and room temperature). Spectra were collected and at $596 \pm 1 \mathrm{~nm}$ evaluated. The results were determined as mg ascorbic acid equivalents (AAE) per kg dry weight (DW). Total polyphenol content was investigated by FolinCiocalteu assay, with modifications of the protocol of Waterhouse (Waterhouse 2002) and given in gallic acid eq. (GAE) mg/kg DW. Suppliers of chemicals used for the antioxidant assays are as follows: DPPH, a. r., Sigma-Aldrich. Folin and Ciocalteu's reagent, 2N, VWR. TPTZ, 98\%, Alfa Aesar. 
HPLC investigations Apparatus: Agilent 1200 Series with diode array detector G1315D Column: ACE C18250 mm*4.6 mm*5 $\mu \mathrm{m}$. Eluent A: aqueous acetic acid (5 V/V\%) and B: acetonitrile. Injection: $10 \mu \mathrm{l}$. The applied gradient is shown in Table 1.

Table 1. Timetable of the gradient program applied to the horsemint extracts.

\begin{tabular}{cc}
\hline $\mathrm{t} \min$ & $\mathrm{ACN} \%$ \\
\hline 0 & 5 \\
5 & 5 \\
8 & 20 \\
11 & 20 \\
13 & 25 \\
16 & 30 \\
22.5 & 25 \\
24.5 & 25 \\
30 & 50 \\
32 & 95 \\
34 & 5 \\
37 & 5 \\
\hline
\end{tabular}

Identification of components was based on retention times of analytical standards. Standards were Caffeic acid, Sigma-Aldrich, min. 99\%, predominantly trans; rosmarinic acid, Aldrich, min. 99\%; Hesperidin, Sigma-Aldrich, min. 97\%, analytical standard; Cynaroside, Sigma-Aldrich, min. 98\%, analytical standard; Diosmin, Sigma-Aldrich, min. 90\%, analytical standard. Solvents: Acetonitrile, VWR Chromanorm, super gradient grade Reag. Ph Eur, USP, ACS. Acetic acid, glacial: VWR AnalAR Normapur.

Quantitation of the identified compounds were based on calibration with their standards. Results here are expressed as the maximal extractable concentration, in mg component/kg dry plant material weight (DW). For each sample, four concentration values were gained for the main phenolics according the different extraction methods described above. These were compared and the maxima were chosen. This approach may better approximate the real concentrations of the ingredients in the plant thus the variability of the concentrations among the 36 populations may be more recognizable. 


\section{RESULTS AND DISCUSSION}

\section{Extractability and antioxidant activity}

The polyphenol contents calculated from the four different extract types has shown a strong solvent dependence. Extractions made with WA were more efficient. Table 2 depicts the basic statistical data for the TPC of four extract types, which are calculated from the detailed results provided in our previous study (Patonay et al. 2019). The similarity of TPC values of the two WA extractions are observable, together with the weak efficiency of $\mathrm{MeOH}$ Soxhlet extraction. In Welch tests, significant difference of the obtained TPC values were observable between the two ultrasound extractions $(p<0.025)$, the two Soxhlets $(p<0.01)$, and between the two methanolic extract types but as it was expected from their similar values, no significant difference was found between the two hydroalcoholic treatments.

Table 2. Comparison of descriptive statistics of TPC of ML samples, calculated from the different extracts. All data is given in mg GAE/kg DW. US stands for 'ultrasonic'.

\begin{tabular}{ccccc}
\hline & MeOH & MeOH & WA & WA \\
& Soxhlet & US & Soxhlet & US \\
\hline Q1 & 25836 & 39143 & 41875 & 46148 \\
Median & 35373 & 47520 & 53721 & 51684 \\
Q3 & 41295 & 55901 & 61351 & 58333 \\
Min & 6295 & 7105 & 18381 & 23390 \\
Max & 49033 & 67952 & 87024 & 67910 \\
\hline
\end{tabular}

The solvent dependence appears in the results of the antioxidant assays, too. WA extractions provide extracts with higher antioxidant activity, than methanolic ones. But additionally, in these assays, dependence on the extraction method is also noticeable. WA sonication was observed to be more efficient than WA Soxhlet, contrary to their similarity in total polyphenol contents. Methanolic Soxhlet extraction resulted in the least efficiency, contrary to its usage appearing in the literature. Basic descriptive statistical data of DPPH $\mathrm{EC}_{50}$ measurements on each extract series are shown in Table 3. The antiradical activity of the four extract types has shown significant differences on the Welch 
test (from $\mathrm{p}<0.025$ to $\mathrm{p}<0.001$ ) in all arrangements of comparisons (two hydroalcoholic extractions, two methanolic extractions, two Soxhlets and two ultrasonic extractions).

Table 3. Comparison of descriptive statistics of $\mathrm{EC}_{50}-\mathrm{mg} / \mathrm{L}$ values of the different ML extracts. US stands for 'ultrasonic'.

\begin{tabular}{ccccc}
\hline & $\begin{array}{c}\text { MeOH } \\
\text { Soxhlet }\end{array}$ & $\begin{array}{c}\text { MeOH } \\
\text { US }\end{array}$ & $\begin{array}{c}\text { WA } \\
\text { Soxhlet }\end{array}$ & $\begin{array}{c}\text { WA } \\
\text { US }\end{array}$ \\
\hline Q1 & 466.7 & 403.9 & 303.2 & 323.1 \\
Q3 & 727.8 & 608.3 & 462.6 & 383.3 \\
Median & 583.1 & 501.6 & 362.1 & 355.8 \\
Min & 353.3 & 291.7 & 168.5 & 226.9 \\
Max & 3183 & 1736 & 983.4 & 806.4 \\
\hline
\end{tabular}

The ferrous reducing activities follow a similar trend as the DPPH data. Methanolic extraction is less efficient, than the WA extractions - partially, methanolic Soxhlet which is found to be the least effective. Sonication with WA is noticed to be more efficient, than WA Soxhlet extraction. The statistical characterization of FRAP values are presented in Table 4.

Table 4. Comparison of descriptive statistics of FRAP values calculated from the different extracts. All data is given in mg AAE $/ \mathrm{kg}$ DW. US stands for 'ultrasonic'.

\begin{tabular}{ccccc}
\hline & $\begin{array}{c}\text { MeOH } \\
\text { Soxhlet }\end{array}$ & $\begin{array}{c}\text { MeOH } \\
\text { US }\end{array}$ & $\begin{array}{c}\text { WA } \\
\text { Soxhlet }\end{array}$ & $\begin{array}{c}\text { WA } \\
\text { US }\end{array}$ \\
\hline Q1 & 5236 & 5498 & 6587 & 7173 \\
Q3 & 6704 & 7301 & 9975 & 10447 \\
Median & 6118 & 6275 & 8017 & 9102 \\
Min & 3264 & 2875 & 3441 & 5671 \\
Max & 7463 & 9101 & 11969 & 12543 \\
\hline
\end{tabular}

The constituents detected in all the thirty-six samples of the horsemint

Six major peaks were observed to appear in all of the extracts and until now, four of them have been identified and quantified. These are, in order of their elutions, the following: i) cynaroside, the 7-0glucoside of luteolin $\left(5,7,3^{\prime}, 4^{\prime}\right.$-tetrahydroxyflavone) ii) diosmin, the 7-0-rutinoside of diosmetin (5,7,3'-trihydroxy-4'-methoxyflavone) iii) hesperidin, 7-0-rutinoside of hesperetin (5,7,3'-trihydroxy-4'- 
methoxyflavanone) and iv) rosmarinic acid, the caffeoyl ester of 3,4-dihydroxyphenyllactic acid. Figure 2 is the chromatogram of a WA Soxhlet extract, also showing the structure of the identified four ingredients and designation of their peaks. Their concentrations in the studied extracts are different, depending on the plant material and, as it is expected, on solvent type. For example, hesperidin is concentrated in methanolic extracts up to $29815 \mathrm{mg} / \mathrm{kg}$ calculated to DW, while it is present in significantly lower concentrations in hydroalcoholic extracts. Identification of the two other major peaks Unknown A and B requires further investigations.

As it was expected, rosmarinic acid is a dominant constituent in the horsemint samples while other hydroxycinnamic acids as major components were not found. Another peculiar trait of the samples is the high concentration of hesperidin. This compound is frequently detected in Mentha plants (Guédon and Pasquier 1994) (Hanafy et al. 2017) but in varying concentrations, not often as a dominant constituent. Diosmin is also frequent in mints, e. g. in peppermint (Guédon and Pasquier 1994). In the case of the horsemint, presence of this compound was only reported once, from a single sample (Bourwieg and Pohl 1973).

Figure 2 shows the distribution of the identified four polyphenols in the thirty-six plant samples and Table 2 summarizes the concentration intervals of them.

As it was expected, a high variability is observable in the concentration of each polyphenol amongst the plant samples.

Table 5. Intervals of the highest extracted concentrations of the identified polyphenols in the thirty-six horsemint samples.

\begin{tabular}{lc}
\hline Component & Highest extracted concentration, mg/kg DW \\
\hline Rosmarinic acid & $7043-38667$ \\
Cynaroside & $<200-2944$ \\
Hesperidin & $1985-29815$ \\
Diosmin & $398-7987$ \\
\hline
\end{tabular}




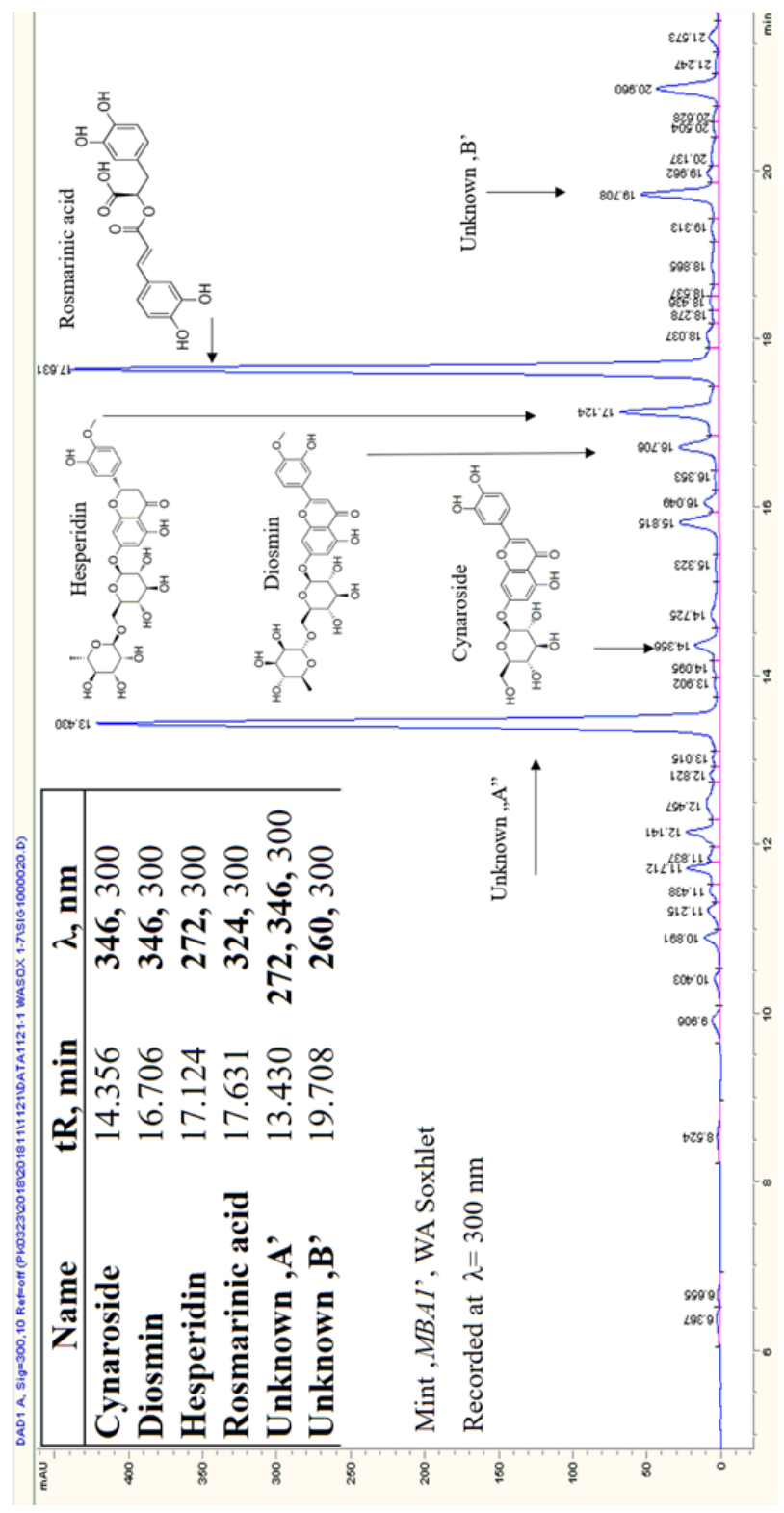

Figure 1. Chromatogram of mint MBA1, WA Soxhlet extract. Table included to the left upper corner contains the retention times of the six common constituents of the mint samples, together with their most intensive detection wavelengths. Structural formulae of the identified four polyphenols are inserted above their peaks. 


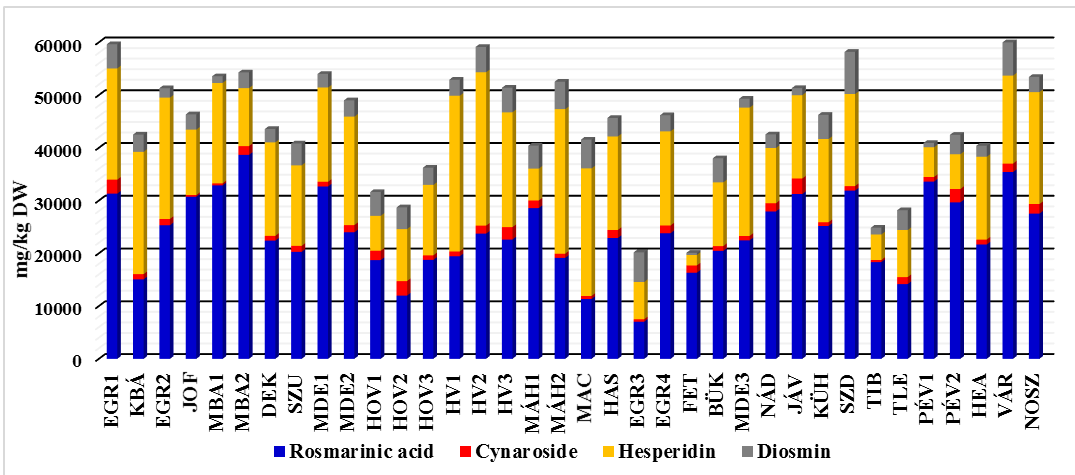

Figure 2. Highest extracted concentrations of the identified polypenols in the horsemint samples, given in $\mathrm{mg} / \mathrm{kg}$ DW. On the x-axis of the chart the sample ID-s are provided.

Antioxidant properties of the identified polyphenols and their connection with the antioxidant capacities of the extracts

Table 6 contains the DPPH and FRAP data measured on the standards of the four identified polyphenols, compared with the values of a widely used control antioxidant, di(tert-)butylhydroxytoluene (BHT or E321).

Table 6. DPPH and FRAP values of the four identified polyphenol compounds in comparison with BHT as positive control.

\begin{tabular}{ccccc}
\hline Standard & \multicolumn{2}{c}{ DPPH EC } & 50 $\mathbf{~ m g / l}$ & \multicolumn{2}{c}{ FRAP mg AAE/kg } \\
\hline & Mean & S. D. & Mean & S. D. \\
\hline Rosmarinic acid & 16 & 0.75 & 172499 & 1044 \\
Cynaroside & 33 & 0.03 & 68637 & 2910 \\
Hesperidin & 6352 & 84.00 & 13333 & 873 \\
Diosmin & $>25000$ & NA & 3098 & 42 \\
BHT & 87.35 & 4.51 & 12169 & 34 \\
\hline
\end{tabular}

Rosmarinic acid and cynaroside were observed to be strong antiradical and reducing agents, being more active than BHT. Rosmarinic acid shows outstandingly strong activity in both antioxidant activity assays, especially in FRAP. This is in accordance with the available literature data each in ferrous reducing activity (Hadjimehdipoor et al. 2014) and in DPPH testing (Damien-Dorman et al. 2003; Koşar et al. 2004). Hesperidin was observed to be a weak antiradical agent and diosmin is practically inactive in both assays. 
The difference in the antiradical activity of cynaroside and the other two flavonoids may be justified with structural background: cynaroside has free $\mathrm{C}^{\prime}-\mathrm{OH}$ and $\mathrm{C}^{\prime}-\mathrm{OH}$ (free catechol moiety) which is highly important in effective radical scavenging (Bors et al. 1990). Contrary to this, in the case of hesperidin and diosmin the C4' site is blocked by a methoxy group. The correlation between the antioxidant properties of the extracts and the concentrations of the four phenolics in them was investigated. Rosmarinic acid concentration was found to be in significant correlation both with the antiradical and the ferrous reducing activity. Strength of correlations of DPPH EC $\mathrm{E}_{50}$ values and rosmarinic acid content of the extracts was medium ( $R$ between 0.4990 and 0.5555 depending on extract type) with $\mathrm{p}<0.01$. To ferrous reducing activity, $\mathrm{R}$ was calculated between 0.3551 and 0.5530 (also in dependence with the extract type) with $\mathrm{p}<0.01$. To cynaroside concentrations, contrary to the high antioxidant activity of this substance, no significant correlation was found with the antioxidant properties of the extracts. No correlation between the two other identified flavonoids and the antioxidant capacities was detected, which is not unexpected regarding the weaker activity of them.

\section{Concluding remarks}

Based on our results, WA may be the appropriate extract type for assuring a high in vitro antiradical activity. Besides, it can be used in food industry without restrictions, contrary to methanol to which strict limitations have been declared (The European Parliament and Council 2009, 2010). The better efficacy of WA than methanol in our study is especially interesting as in numerous former references methanol was frequently used as a polar medium to gain polyphenolic antioxidants of the plant.

The investigated horsemint samples contained high levels of rosmarinic acid. Concentration of this constituent may reach high values also in other mints: $0.97-3.86 \mathrm{~m} / \mathrm{m} \% \mathrm{DW}$, ca. $9700-38600$ $\mathrm{mg} / \mathrm{kg}$ were observed in a survey dealing with 40 different samples of different peppermint cultivars (Guédon and Pasquier 1994). Our findings show, that horsemint may be a useful source of polyphenolic antioxidants, too. The high amount of hesperidin and the lack of caffeic acid in higher ratios was unexpected in comparison with literature of ML (Dudai et al. 2006). The presence of diosmin and its concentration intervals are also similar to the 
values of peppermint detected in the aforementioned study (0.03$0.47 \mathrm{~m} / \mathrm{m} \%$, ca. $300-4700 \mathrm{mg} / \mathrm{kg}$ DW). A medium, significant correlation between rosmarinic acid content and antioxidant properties of samples was determined while the connection of antioxidant power and content of cynaroside was not significant. These results indicate that identification and quantification of Unknown A and B in the extracts would be necessary to decide how flavonoids and other polyphenols beyond rosmarinic acid contribute to the antioxidant properties of horsemint. The investigation discussed above is part of the first phytochemical survey of horsemint populations in Hungary. The high heterogeneity of concentration of the phenolics in the horsemint samples supports the assumption that the wild-collected material is not suitable for gaining extracts of standard quality. Selection, propagation and cultivation of ML chemotypes bearing the required polyphenol composition may provide a sustainable alternative.

Acknowledgements: Authors gratefully acknowledge support of the grant EFOP3.6.1-16-2016-00001 'Complex improvement of research capacities and services at Eszterhazy Karoly University' and the valuable support of Bükk National Park in this project.

\section{REFERENCES}

Ahmed, D., Khan, M.M. \& SAEed, R. (2015). Comparative analysis of phenolics, flavonoids, and antioxidant and antibacterial potential of methanolic, hexanic and aqueous extracts from Adiantum caudatum leaves. Antioxidants 4: 394409. https://doi.org/10.3390/antiox4020394

Ali, M. S., Saleem, M., Ahmad, W., Parvez, M. \& Yarudani, R. (2002). A chlorinated monoterpene ketone, acylated glycosides of beta-sitosterol and a flavonoid glycoside of Mentha longifolia. Phytochemistry 59: 889-895. https://doi.org/10.1016/S0031-9422(01)00490-3

Bahadori, B. M., Zengin, G., BAHAdori, S. \& DinParast, L. (2018). Phenolic composition and functional properties of wild mint (Mentha longifolia var. calliantha (Stapf) Briq.). International Journal of Food Properties 21: 183-193. https://doi.org/10.1080/10942912.2018.1440238

BAŞER, K.H.C., KÜRKÇÜOĞLU, M., TARIMClLAR, G. \& KAYNAK, G. (1999). Essential oils of Mentha species from Northern Turkey. Journal of Essential Oil Research 11: 579-588. https://doi.org/10.1080/10412905.1999.9701218

Benedec, D., Vlase, L., Oniga, I., Mot, A.C., Silaghi-Dumitrescu, R., Hanganu, D., TIPERCIUC, B.T. \& CRISAN, G. (2013). LC-MS analysis and AO activity of phenolic 
compounds from two indigenous species of Mentha. Note I. Farmacia 61: 262267.

BENZIE, I.F.F. \& STRAIN, J.J. (1996). The ferric reduction ability of plasma (FRAP) as a measure of "Antioxidant Power": the FRAP assay. Analytical Biochemistry 239: 70-76. https://doi.org/10.1006/abio.1996.0292

Bors, W., Heller, W., Michel, C. \& SARAN, M. (1990). Flavonoids as antioxidants: Determination of radical-scavenging efficiencies. Methods in Enzymology 186: 343-355. https://doi.org/10.1016/0076-6879(90)86128-I

Bourwieg, D., \& Pohl, R. (1973). The flavonoids of Mentha longifolia. Planta Medica 24: 304-314.

Damien-Dorman, H. J., Koşar, M., Kahlos K, Holm, Y., Hiltunen, R. (2003). Antioxidant properties and composition of aqueous extracts from Mentha species, hybrids, varieties, and cultivars. Journal of Agricultural and Food Chemistry 51: 45634569. https://doi.org/10.1021/jf034108k

Dudai, N., Segev, D., Havkin-Frenkel, D. \& Eshel, A. (2006). Genetic variation of phenolic compounds content, essential oil composition and antioxidative activity in Israel-grown Mentha longifolia L. Acta Horticulturae 709: 69-78. https://doi.org/10.17660/ActaHortic.2006.709.8

Fialová, S., Tekel'ová, D., MrlianovÁ, M. \& Grančai, D. (2008). The determination of phenolic compounds and antioxidant activity of mints and balms cultivated in Slovakia. Acta Facultatis Pharmaceuticae Universitatis Comenianae 54: 96-102.

Ghoulami, S., IL-IDRISSI, A. \& FKIH-Tetouani, S. (2001). Phytochemical study of Mentha longifolia of Morocco. Fitoterapia 72: 596-598. https://doi.org/10.1016/S0367-326X(01)00279-9

GuÉDON, D.J. \& PASQUIER, B.P. (1994). Analysis and distribution of flavonoid glycosides and rosmarinic acid in 40 Mentha $x$ piperita clones. Journal of Agricultural and Food Chemistry 42: 679-684. https://doi.org/10.1021/jf00039a015

Güllüce, M., Sahin, F., Sokmen, M., Ozer, H., Daferera, D., SoKmen, A., Polissiou, M., AdiguZEL, A., \& OZKAN, H. (2007). Antimicrobial and antioxidant properties of essential oils and methanolic extract from Mentha longifolia ssp. longifolia. Food Chemistry 103: 1449-1456. https://doi.org/10.1016/j.foodchem.2006.10.061

Hajimehdipoor, H., Shahrestani, R. \& SheKarchi, M. (2014). Investigating the synergistic antioxidant effects of some flavonoid and phenolic compounds. Research Journal of Pharmacognosy 1: 35-40.

Hajlaoui, H., Trabelsi, N., Noumi, E., Snoussi, M., Fallah, H., Ksouri, R. \& Bakhrouf, A. (2009). Biological activities of the essential oils and methanol extract of two cultivated mint species (Mentha longifolia and Mentha pulegium) used in the Tunisian folkloric medicine. World Journal of Microbiology and Biotechnology 25: 2227-2238. https://doi.org/10.1007/s11274-009-0130-3

Hanafy, D.M., Prenzler, P.D., Burrows, G.E., Ryan, D., Nielsen, S., El SaWi, S.A., El Alfy, T.S., Abdelrahman, E.H., Hassan, K., OBied, H.K. (2017). Biophenols of mints: Antioxidant, acetylcholinesterase, butyrylcholinesterase and histone deacetylase inhibition activities targeting Alzheimer's disease treatment. Journal of Functional Foods 33: 345-362.

https://doi.org/10.1016/j.jff.2017.03.027 
HAWryŁ, M. A., Niemiec, M., SŁomka, K., WaksmundzKa-Hajnos, M. \& SzimcZAK, G. (2016). Micro-2D-TLC Separation of phenolics in some species of mint and their fingerprints on diol bonded polar stationary phase. Acta Chromatographica 28: 119-127. https://doi.org/10.1556/achrom.28.2016.1.9

Iqbal, T., Hussain, A. I., Shahid Chatha, S. A., Naqvi, S. A. R. \& Hussain Bokhari, T. (2013). Antioxidant activity and volatile and phenolic profiles of essential oil and different extracts of wild mint (Mentha longifolia) from the Pakistani flora. Journal of Analytical Methods in Chemistry 2013: ID 536490. https://doi.org/10.1155/2013/536490

Jahan, N., Malik, A. \& Muhammad, P. (2001). New flavonoid from Mentha longifolia. Heterocycles 55: 1951-1956. https://doi.org/10.3987/COM-01-9281

Karabegović, I. T., Nikolova, M., Velicković, D., Stojičević, S., Veljoović, V. \& Lazić, M. (2011). Comparison of antioxidant and antimicrobial activities of methanolic extracts of the Artemisia sp. recovered by different extraction techniques Chinese Journal of Chemical Engineering 19: 504-511. https://doi.org/10.1016/S1004-9541(11)60013-X

Koşar, M., Damien Dorman, H.J., Başer, K.H.C. \& Hiltunen, R. (2004). Screening of free radical scavenging compounds in water extracts of Mentha samples using a postcolumn derivatization method Journal of Agricultural and Food Chemistry 52: 5004-5010. https://doi.org/10.1021/jf0496189

Kőszeginé Szalai, H., TöröK, I., Ráfliné Romvári, Zs., Nagy, A., Fejér, I., Kertész, P., Posgayné Kovács, E., \& VAnKó, É. (eds.) (2003). Magyar Gyógyszerkönyv I-II. (Pharmacopoea Hungarica). Medicina Könyvkiadó Rt., Budapest, 2504+76 p.

Krzyzanowska, J., Janda, B., Pecio, L., Stochmal, A. \& Oleszek, W. (2011). Determination of polyphenols in Mentha longifolia and M. piperita field-grown and in vitro plant samples using UPLC-TQ-MS. Journal of AOAC International 94: 43-50. https://doi.org/10.1093/jaoac/94.1.43

Medina-Torres, N., Ayora-Talavera, T., Espinosa-Andrews, H., SÁnchez-Contreras, A. \& PACHECo, N. (2017). Ultrasound assisted extraction for the recovery of phenolic compounds from vegetable sources. Agronomy 7(3): 47.

https://doi.org/10.3390/agronomy7030047

Mimica-Dukić, N., Jakovljevic, V., Popovic, M., Szabo, A. \& Gašic, O. (1999). Pharmacological studies of Mentha longifolia phenolic extracts II. Hepatoprotective activity. Pharmaceutical Biology 37:221-224.

https://doi.org/10.1076/phbi.37.3.221.6306

Murad, H.A.S., ABDALLAH, H.M., \& Ali, S.S. (2016). Mentha longifolia protects against acetic-acid induced colitis in rats. Journal of Ethnopharmacology 190: 354-361. https://doi.org/10.1016/j.jep.2016.06.016

OnIsZczuK, A. \& PODGóRSKI, R. (2015). Influence of different extraction methods on the quantification of selected flavonoids and phenolic acids from Tilia cordata inflorescence. Industrial Crops and Products 76: 509-514.

https://doi.org/10.1016/j.indcrop.2015.07.003

Paniwnyk, L., Cai, H., Albu, S., Mason, T.J., \& Cole, R. (2009). The enhancement and scale up of the extraction of anti-oxidants from Rosmarinus officinalis using ultrasound. Ultrasonics Sonochemistry 16: 287-292.

https://doi.org/10.1016/j.ultsonch.2008.06.007 
PARK, Y.J., BAeK, S.A., Chol, Y., Kim, J.K. \& PARK, S.U. (2019). Metabolic profiling of nine Mentha species and prediction of their antioxidant properties using chemometrics. Molecules 24: 258-273.

https://doi.org/10.3390/molecules24020258

Patonay, K., Korózs, M., Murányi, Z. \& PÉnzesné Kónya, E. (2017). Polyphenols in northern Hungarian Mentha longifolia (L.) L. treated with ultrasonic extraction for potential oenological uses Turkish Journal of Agriculture and Forestry 41: 208-217. https://doi.org/10.3906/tar-1701-61

Patonay, K., Szalontai, H., Csugány, J., Szabó-Hudák, O., Helga Pénzesné, Kónya E. \& ZÁmboriné NÉmeth, É. (2019). Comparison of extraction methods for the assessment of total polyphenol content and in vitro antioxidant capacity of horsemint (Mentha longifolia (L.) L.) Journal of Applied Research on Medicinal and Aromatic Plants 15: 100220.

https://doi.org/10.1016/j.jarmap.2019.100220

Pereira, O.R., \& CARdoso, S.M. (2013). Overview of Mentha and Thymus polyphenols. Current Analytical Chemistry 9: 382-396. https://doi.org/10.2174/1573411011309030008

Sharaf, M., El-AnSARI, M., \& SALEH, N.A.M. (1999). Flavonoid glycosides from Mentha longifolia. Fitoterapia 70: 478-483.

https://doi.org/10.1016/S0367-326X(99)00062-3

Sharopov, F.S., Sulaimanova, V.A., \& SETZER, W.N. (2012). Essential oil composition of Mentha longifolia from wild populations growing in Tajikistan. Journal of Medicinally Active Plants 1: 76-84. https://doi.org/10.7275/R5736NTN

Shen, D., Pan, H.M., Wu, Q.L., Park, C.H., Rodolfo Juliani, H., Ho, C.T. \& Simon, J.E. (2011). A rapid LC/MS/MS method for the analysis of nonvolatile antiinflammatory agents from Mentha spp. Journal of Food Science 76(6): 900908. https://doi.org/10.1111/j.1750-3841.2011.02281.x

Simon, T. (1994). A magyarországi edényes flóra határozója: Harasztok - virágos növények. (Handbook of the Hungarian vascular flora. Ferns and seed plants). Nemzeti Tankönyvkiadó Rt., Budapest, 845 p.

Stanislavljević, D.M., STojičević, S.S., ĐorĐević, S.M., Zlatković, B.P., VeličKović, D.T. \& KARABEGOVIĆ, I.T. (2012). Antioxidant activity, the content of total phenols and flavonoids in the ethanol extracts of Mentha longifolia L. dried by the use of different techniques. Chemical Industry and Chemical Engineering Quarterly 18: 411-420. https://doi.org/10.2298/CICEQ110919017S

The European Parliament and Council (2009). Directive 2009/32/EC of the European Parliament and Council of 23 April 2009 on the approximation of the laws of the Member States on extraction solvents used in the production of foodstuffs and food ingredients. Official Journal of the European Union 141: 37.

The European Parliament and Council (2010). Directive 2010/59/EC of the European Parliament and Council of 26 August 2010 amending Directive 2009/32/EC of the European Parliament and of the Council on the approximation of the laws of the Member States on extraction solvents used in the production of foodstuffs and food ingredients. Official Journal of the European Union 225: 10-12.

TUCKER, A.O. \& NACZI, R.F.C. (2007). Mentha: An overview of its classification and relationships. In: LaWrencE, B.M.(ed.): Mint. The genus Mentha - Medicinal and 
aromatic plants - Industrial profiles. CRC Press, Taylor and Francis Group, Boca Raton, pp. 3-39.

Waterhouse, A.L. (2002). Determination of total phenolics. Current Protocols in Food Analytical Chemistry 6(1): I1.1.1-I1.1.8.

https://doi.org/10.1002/0471142913.fai0101s06

(submitted: 07.01.2020, accepted: 09.09.2020) 